MARZENA BUCHNAT, ANETA WOJCIECHOWSKA Adam Mickiewicz University, Poznań, Poland

\title{
Online education of students with mild intellectual disability and autism spectrum disorder during the COVID-19 pandemic
}

\begin{abstract}
Marzena Buchnat, Aneta Wojciechowska, Online education of students with mild intellectual disability and autism spectrum disorder during the COVID-19 pandemic. Interdisciplinary Contexts of Special Pedagogy, no. 29, Poznań 2020. Pp. 149-171. Adam Mickiewicz University Press. ISSN 2300-391X. e-ISSN 2658-283X. DOI: https://doi.org/10.14746/ikps.2020.29.07

The situation of the pandemic of SARS-CoV-2 virus that causes COVID-19 disease is a new and unknown situation for everyone, causing fear and uncertainty. It is also a situation that has led to numerous changes in the everyday life of many people, including students who had to adapt to the new reality of distance education from day to day. The paper concerns with the situation of online education of students with mild intellectual disability and autism spectrum disorder. It is an attempt to indicate the difficulties encountered by this group of students in the situation of distance learning from a perspective of both the student and the teacher. The paper also indicates the issues which should be considered in this education, the way of its adaptation to the possibilities of the discussed group of students, as well as elements which are really important in this education.
\end{abstract}

KEY WORDS: online teaching, student with mild intellectual disability, student with ASD, COVID-19 


\section{Introduction}

The pandemic of SARS-CoV-2 virus that causes COVID-19 disease has caused a crisis in various areas of social life. This situation surprised and even exceeded expectations of numerous adults, let alone children. Disintegration of everyday life in all its areas of rest, study, work, social contacts causes strong, primarily negative emotions. The threat of disease as well as impaired functioning on many levels causes a strong fear that most of the society has to face. The pandemic has also changed the child's world - including the way of school operation, because education has been moved to distance mode. Changing the way of teaching, social isolation and a widespread crisis causing emotional burden is a huge challenge for children and adolescents, especially those for whom such changes are difficult to understand such as: children with mild intellectual disability and autism spectrum disorder (ASD). The article provides the analysis of the way this group of students deals with the new reality of distance school education.

\section{Cognitive abilities of students with an intellectual disability and students with ASD}

Distance education introduced to schools is a completely new situation for students, as well as parents and teachers. Until now, elearning has been conducted as an additional form, and it was one of the possibilities to use. Currently, it constitutes the only available method of education. In the case of students with mild intellectual disability and students with ASD, this can be a challenge, because as reported by Z. Gajdzica ${ }^{1}$, they require special approach to their educational needs. This means that education should be adapted to their abilities and needs, which are different because of their level of functioning.

1 Z. Gajdzica (2011), Sytuacje trudne w opinii nauczycieli klas integracyjnych, Kraków, Oficyna Wydawnicza „Impuls”. 
The basic prerequisite for working with students with mild intellectual disability is significant substantiation resulting from the achieved level of thinking. The consequence of the inability to master the level of abstract and hypothetical-deductive reasoning are difficulties in analysing, synthesising, abstracting, and generalising. ${ }^{2}$ They cause that the education of these children must be based on the concrete reality on the basis of which the teacher will guide the child through individual processes to obtain final conclusions. During the analysis of a task, children with mild intellectual disability, because of their concrete level of thinking, often make mistakes regarding both logic and losing threads, and reveal inability to generalise or abstract. Rigid thinking and low ability to stop their reactions results in their worse adaptation to the changing conditions of cognition. Lack of thorough analysis of the task, referring it to previous experience and making a critical assessment of undertaken actions means that children with mild intellectual disability usually learn by trial and error, rather than planned strategies that are most effective for a given individual. All these factors cause deficits in receiving information. On the other hand, inaccurate information gathering may be one of the reasons for the lack of success in the further learning proces. ${ }^{3}$

Unfortunately, difficulties in thinking prevent the use of better and better memory strategies ${ }^{4}$, which determines the limitation in this respect. These students have problems in all memory processes, from coding acquired information, through actively maintaining information in the articulatory loop, to the general short-term and long-term memory deficyt. ${ }^{5}$ Deficits in the area of information re-

2 J. Wyczesany, Z. Gajdzica (2006), Uwarunkowania edukacji i rehabilitacji uczniów o specjalnych potrzebach rozwoju, Kraków, Wyd. Naukowe AP, p. 69.

${ }^{3}$ M. Buchnat (2015), Formy organizacyjne ksztatcenia dziecka z lekka niepetnosprawnościa intelektualna a jego kompetencje społeczne, Poznań, Wydawnictwo Naukowe UAM, pp. 35-43.

${ }^{4}$ R. Stefańska-Klar R. (2005), Późne dzieciństwo. Młodszy wiek szkolny, [in:] B. Harwas-Napierała, J. Trempała (red.), Psychologia rozwoju człowieka (vol. 2, pp. 130-163), Warsaw, Wyd. Naukowe PWN, p. 135.

${ }^{5}$ E. Nęcka (2003), Inteligencja: geneza - struktura - funkcje, Gdańsk, GWP, pp. 182-185. 
tention strategies result in reduced memory persistence. They better memorise material related to their own experience, based on emotions, which is stored in episodic memory. This type of memory in children with mild intellectual disability is present at the level of normal children. However, significant limitation is observed in terms of semantic memory, because memorisation of language messages that form the knowledge system requires complex conceptual operations that are disturbed. ${ }^{6}$ Therefore, students with mild intellectual disability require polisensory cognition, during the activity preferably associated with emotions and frequent repetitions, so that the material is remembered. It is also important that they can use the newly acquired knowledge in practice, otherwise they often learn without understanding. ${ }^{7}$ Because the attention of these children is poorly split and alternating, and easily distracted, they require elimination of stimuli that interfere with the learning process. Elimination of interfering stimuli is both necessary in the child's environment and reflected in the proper construction of teaching aids and worksheets. Low split attention skills mean that these children cannot effectively use various sources in the process of acquiring information.

The reduction of unwanted stimuli and properly prepared didactic material are also justified by limitation in the area of perception. The process of perception in children with mild intellectual disability is limited, which makes the perception of reality simplified and quite poor. These children do not notice the details or the occurring relationships, which results in a superficial acquisition of information. This situation is aggravated by the aforementioned deficits in concentration of attention, which further impede the acquisition of data needed to solve a specific task. Auditory and visual perception disorders also have an impact on inaccuracy, a smaller range and a slower pace of perception. These disorders affect the

${ }^{6}$ R. Kościelak (1989), Psychologiczne podstawy upośledzonych umystowo, Warsaw, Wyd. Naukowe PWN p. 48.

7 J. Głodkowska (2000), Pomóżmy dziecku z upośledzeniem umystowym doświadczać przestrzeni, Warsaw, Wyd. WSPS. p. 68. 
inaccuracy of perception, which results in the fact that children with mild intellectual disability have a distorted perception of reality. They mainly notice the external characteristics of objects, e.g. colour, ignoring their detailed features. They have a problem with placing them in space and shaping their concept. This level of perception causes difficulties in comparing objects, finding their similarities and differences, as well as noticing interrelationships. Children with mild intellectual disability perceive much less objects at a given time than children with normal intellectual capacity, which results from the slower course of cortical processes, and the perception of the surrounding reality is even poorer. ${ }^{8}$

Difficulties in cognitive processes also affect the language development of children with mild intellectual disability in all areas which include: lexical, morphosyntactic, phonological and pragmatic ones. ${ }^{9}$ Limited vocabulary range, lack of understanding of the interlocutor's messages, their location in a given reality, causes a lot of communication disruptions. It happens that students with mild intellectual disability misunderstand verbal instructions on how to perform a task and do not know what information to look for. Therefore, the formulated instructions, materials for independent reading or listening to must be properly prepared in a way to be understood by the child.

As a result of such a course of cognitive development, these children show a low degree of cognitive interests, are not very inventive, passive in thought, and unfortunately also have a fairly low level of motivation to learn. Building both external and internal motivation in children with mild intellectual disability is largely difficult. Internal motivation requires the ability to analyse one's own actions. It is difficult for these students to analyse and under-

${ }^{8}$ M. Buchnat (2015), Formy organizacyjne kształcenia dziecka z lekka niepetnosprawnościa intelektualna a jego kompetencje społeczne, Poznań, Wydawnictwo Naukowe UAM, p. 40; J. Wyczesany, Z. Gajdzica (2006), Uwarunkowania edukacji i rehabilitacji uczniów o specjalnych potrzebach rozwoju, Kraków, Wyd. Naukowe AP, p. 68.

${ }^{9}$ U. Jęczeń (2003), Uwarunkowania rozwoju kompetencji językowej i komunikacyjnej u dzieci upośledzonych umysłowo, Logopedia, 32, pp. 127-138. 
stand the reasons for undertaken actions, as well as to track the course of their own actions and subject it to critical analysis. In building external motivation, ideological and world-view-related reasons or universal human values are too abstract for them and do not increase their activity.

Cognitive reasons are also not effective because of the low level of their cognitive activity. The most effective strengtheners are specific stimuli that correspond to the level of thinking of these children and provide a noticeable signal for them to change their behaviour. Therefore, children with mild intellectual disability show the greatest learning effectiveness when they are focused on achieving a specific goal, especially when this process takes place in a collaboration-oriented group. ${ }^{10}$

Deficits present in children with mild intellectual disability are also characteristic of children with autism spectrum disorder. If the cognitive abilities of a student with ASD are discussed, the above difficulties should be considered in the case of a child with multiple disabilities: intellectual disability and ASD. This multiple disability may relate to different degrees of intellectual disability and autism spectrum disorder, however, in the present paper special attention is focused on children with ASD having normal intellectual capacity or with mild intellectual disability and children with mild intellectual disability alone.

On the one hand, the learning abilities of a child with autism spectrum disorder are conditioned by specific processes related to cognitive abilities that are the same as those described above for students with intellectual disability, and on the other hand, by specific features characteristic of ASD. Students with autism spectrum disorder have psychoeducational profiles that are characterised by uneven development patterns. Studies indicate that deficits in numerous cognitive functions may occur, but this does not apply to all people with ASD. Intellectual disability occurs in most people with

10 D. Mitchell (2008), What Really Works in Special and Inclusive Education, London -New York, Routledge. 
autism ${ }^{11}$, which means that the learning processes of this group of students should be considered depending on the cognitive abilities of each student. In the case of the presence of intellectual disability, it can be assumed that learning processes are similar to the learning processes in children and adolescents with different degrees of intellectual disability. The above-mentioned difficulties, are additionally accompanied by problems in the area of speech and communication, greater difficulties in the area of social understanding and learning, as well as more common behaviour interfering with the acquisition of knowledge, such as stereotypes, stimulations, routine, etc.

The involvement in the surrounding world of a child with ASD from an early age is definitely lower compared to children without this disorder. Exploration of the environment and desire to learn provide the opportunity to practice different skills and acquire knowledge relevant for cognitive and social development. The low level of involvement, especially in the social aspect of life, limits learning abilities for children with ASD. ${ }^{12}$ One of the basic problems in social learning is the difficulty in acquiring skills by imitation, which is the basis of learning as early as in infancy in areas such as play, speech and social functioning. Deficiencies in this respect observed in people with ASD already in the preschool period, affect learning. This is because this ability first determines the basis for further acquisition of basic communication skills, and in later periods also gives the opportunity to effectively learn social communication, peer relationships, but also provides the basis for seeking ways to solve numerous everyday problems. ${ }^{13}$

11 G. La Malfa, S. Lassi, M. Bertelli, R. Salvini, G.F. Placidi (2004), Autism and intellectual disability: a study of prevalence on a sample of the Italian population, Journal of Intellectual Disability Research, 48(3), pp. 262-267; A.L. Hedvall (2014), Autism in preschool children: Cognitive aspects and interventions, Printed in Gothenburg, Sweden, Ale Tryckteam, Bohus.

12 D. Keen (2009), Engagement of Children with Autism in Learning, Australasian Journal of Special Education, Volume 33, Issue 2, pp. 130-140.

13 E. Pisula (2015), Autyzm. Od badań mózgu do praktyki psychologicznej, Gdańsk, GWP; H. Sowden, M. Perkins, J. Clegg (2008), The co-development of speech and gesture 
In addition to difficulties in the social area, impairment of social cognition, including deficiencies in the ability to split attention, notice and recognise the emotions of other people, deficits in the area of prediction and conclusion concerning emotional states and beliefs of other people, and so in everything that form theory of mind, can be noticed.

In the course of cognitive processes characteristic of people with ASD, disorders at the level of central coherence, which in educational practice causes deficiencies in paying attention to important tips and information, and directing it often to elements of little importance and sometimes unnecessary, is also noticed. The weak central coherence theory concerns limitation of the ability to understand the context or excessive attention to details in people with ASD. Weak central coherence may cause difficulties in receiving information from various areas, including non-verbal and verbal communication (e.g. difficulties in understanding complex messages with a lot of information, focusing on unimportant elements of a statement). Difficulties in this area are recognised as a different perceptive and cognitive style, which is of great importance for the communication and social functioning of a person with ASD. ${ }^{14}$ Numerous more complex difficulties in the reception of social communication result from a disorder in the development of theory of mind, which in turn makes it difficult to assess, among others, the intentionality of people, non-verbal communication, understanding of metaphorical, figurative, ambiguous language, and cause difficulties in tasks involving imagination, pretending, creating situations, etc. ${ }^{15}$

in children with autism, Clinical Linguistics and Phonetics, 22 (10-11), pp. 804-813; A. Cangialose, P.J. Allen (2014), Screening for autism spectrum disorders in infants before 18 months of age: Pediatric nursing 40(1), pp. 33-37.

${ }^{14}$ U. Frith (2008), Autyzm: Wyjaśnienie tajemnicy, Gdańsk, GWP.

${ }^{15}$ See: M. Prentka (2015), Aetiology of Theory of Mind disorders for people with Autism Spectrum Disorder. Neurocognitive therapeutic intervention: Transdyscyplinarne Studia o Kulturze (i) Edukacji, 10, pp. 87-100; A. Pluta (2012), Mechanizmy poznawcze teorii umysłu: Roczniki psychologiczne, volume XV, no. 1, pp. 7-30; 
Students with ASD also have problems in planning their activities, as well as difficulties in undertaking actions related to solving a problem. This is related to the above areas, or understanding social situations and the skills to effectively plan problem solving strategies. In addition, they have difficulties with mental flexibility, generating new ideas and self-control.

The strong point of students with ASD is memory, especially visual memory. They memorise visual material more easily than the one transmitted in other forms or without the possibility of visual support. This sphere also positively affects the performance of tasks based on visual and visual-spatial perception. Therefore, people with ASD achieve significantly higher results on a non-verbal scale than on a verbal scale in tests involving the study of learnt functions. In these studies it was also observed that they deal better with abstract problems than with analysing problems related to social situations. Similarly, they achieve lower results in subtests concerning vocabulary and understanding. 16

People with ASD also have difficulty in learning information patterns, which is associated with problems with learning basic event strategies if the strategy of hypothesis testing cannot be used. Studies also indicate that people with ASD have difficulties in implicit and latent learning, and this way of learning is more effective also in language learning, approaches to solving mathematical problems, etc. The performance of implicit learning tasks is strongly correlated with ASD symptomatology, including communication skills, social skills, and the occurrence of repetitive behaviour.

S. Baron-Cohen (2001), Theory of mind in normal development and autism: Prisme, 34, pp. 174-183; M. Dekowska, P. Jaśkowski (2011), W świecie masek, czyli o tym, jak osoby z autyzmem spostrzegaj ludzką twarz: Roczniki psychologiczne, volume XIV, no. 1, pp. 91-125.

${ }_{16}$ V.E.A. Brunsdon, E. Colvert, C. Ames, T. Garnett, N. Gillan, V. Hallett, S. Lietz, E. Woodhouse, P. Bolton, F. Happe (2015), Exploring the cognitive features in children with autism spectrum disorder, their co-twins, and typically developing children within a population - based sample, Journal of Child Psychology and Psychiatry, 56: 8, pp. 893-902. 
At the level of executive functions, people with ASD also have difficulty in splitting attention, persistent pursuit of the task, and they experience lack of impulse control. ${ }^{17}$

\section{Distance education of students with disability}

Deficits in children with mild intellectual disability and in children with autism spectrum disorder determine the overall picture of learning difficulties specific to this group of children that must be considered in conducting education - distance education of these students.

Distance education of students with mild intellectual disability and ASD requires teachers to prepare it in a special way, and to find the right way to implement it that meets the needs and abilities of these students. There are many premises that indicate that distance education can support the development of people with special educational needs, but unfortunately also cause their further marginalisation. In the current compulsion of distance education, one of the problems determining the quality of education includes digital competence of students, their parents, as well as teachers, necessary for participation in this form of education. Previous studies in this area have revealed that they are at a very differentiated level ${ }^{18}$, and

17 J.L. Amaral, S. Collins, K.T. Bohache, H. Kloos (2012), Beyond the Black-andWhite of Autism: How Cognitive Performance Varies with Context, [in:] Current Topics in Children's Learning and Cognition, edited by Heidi Kloos, Bradley Morris,Joseph Amaral, chapter 6, pp. 105-122.

18 S. Cortesi, A. Hasse, A. Lombana-Bermudez, S. Kim, U. Gasser (2020). Youth and digital citizenship+ (plus): Understanding skills for a digital world. Youth and Media, Berkman Klein Center for Internet $\mathcal{E}$ Society. Retrieved from: https://cyber.harvard. edu/publication/2020/youth-and-digital-citizenship-plus (access: 20.05.2020); J. Pyżalski (2019a), Cyfrowa pedagogika medialna, [in:] Z. Kwieciński, B. Śliwerski (ed.), Pedagogika. Podręcznik akademicki, Warsaw, Wydawnictwo Naukowe PWN SA; D. Smahel, H. Machackova, G. Mascheroni, L. Dedkova, E. Staksrud, K. Ólafsson, S. Livingstone, U. Hasebrink (2020), EU Kids Online 2020: Survey results from 19 countries. EU Kids Online. 
in the current situation it is difficult to improve them. This is even more important because owing to the pandemic, it is not possible to choose the way of education, and thus to supplement or explain issues that the children did not understand online. The problem may also be the availability of computer equipment or broadband Internet, which is the basis of distance education. The study conducted by Piotr Plichta ${ }^{19}$ revealed that people with a disability have less access to such tools, thus confirming the existence of digital inequalities in this social group. However, this author ${ }^{20}$ points out that limitations in terms of competence are a much more serious challenge in the pedagogical perspective.

International studies ${ }^{21}$ reveal that students with disabilities experience barriers to direct access to e-learning courses. In the study conducted by J.B. Roberts, L.A. Crittenden and J.C. Crittenden ${ }^{22}$, almost half of students with a disability declared that their disa-

19 P. Plichta (2018), The use of information and communication technologies by young people with intellectual disabilities in the context of digital inequalities and digital exclusion, "E-Methodology", 5, pp. 11-23.

20 P. Plichta, Różne konteksty nierówności cyfrowych a wyzwania dla zdalnej edukacji - propozycje rozwiązań, [in:] Edukacja w czasach pandemii wirusa COVID-19. Z dystansem o tym, co robimy obecnie jako nauczyciele, ed. J. Pyżalski, Warsaw, EduAkcja, 2020, p. 71.

21 Among others: N. Coombs (2010), Making online teaching accessible: Inclusive course design for students with disabilities. San Francisco, Jossey-Bass; C.S. Fichten, V. Ferraro, J.V. Asuncion, C. Chwojka, M. Barile, M.N. Nguyen, R. Klomp, J. Wolforth, (2009)1 Disabilities and e-learning problems and solutions: An exploratory study. Educational Technology and Society, 12(4), 241-256; C.G. Keeler, M. Horney (2007). Online course de-signs: Are special needs being met? American Journal of Distance Education, 21(2), 61-75; National Council on Disability (2004). Design for inclusion: Creating a new marketplace. National Council on Disability Website. Retrieved from http://www. ncd.gov/newsroom/publications/2004/online_newmar ketplace.htm; R. Thomson, C.S. Fichten, A. Havel, J. Budd, J. Asuncion (2015), Blending universal design, e-learning, and information and communication technologies. In S. Burgstahler (ed.), Universal design in higher education: From principles to practice (pp. 275-284). Cambridge, MA, Harvard Education Press.

22 J.B. Roberts, L.A. Crittenden, J.C. Crittenden (2011), Students with disabilities and online learning: A cross-institutional study of perceived satisfaction with accessibility compliances and services. Internet and Higher Education, 14(4), pp. 242-250. 
bility had a negative impact on their success during online classes. In another study, female students with a disability and learning difficulties declared that they had not received adequate support and were less satisfied with online courses than women who had no learning difficulties. ${ }^{23}$ It is believed that even those people with a disability who have access to digital technologies are unable to reap all the benefits which this technology provides to other people. ${ }^{24}$ These inequalities are noticeable, despite the fact that studies of differences in the performance of student subgroups by gender, age or race rarely analyse differences between students with disabilities. ${ }^{25}$ In order to eliminate these differences, activities aimed at ensuring universal access to online learning are being conducted. World Wide Web Consortium (W3C), introduced Web Accessibility Initiative (WAI) ${ }^{26}$ in order to develop guidelines for web design accessible to everyone, including people with disabilities, but also those with temporary disabilities or people with variable abilities due to ageing

The guidelines developed by WAI, based on the four principles of accessibility (visibility, comprehensibility, feasibility, reliability) are aimed at creating web content accessible to people with disabilities. They are focused on the following quick tips:

1.1. Text alternatives - provide text alternatives for any non-text content so that it can be changed into other forms people need, such as braille, speech, symbols, or simpler language.

1.2. Time-based media - provide alternatives for time-based media.

1.3. Adaptable - create content that can be presented in different ways without losing information or structure.

23 T. Heiman (2008), Females with learning disabilities taking on-line courses: Perceptions of the learning environments, coping and well-being, Journal of Postsecondary Education and Disability, 21(1), pp. 4-14.

24 S. Burgstahler (2015), Opening Doors or Slamming Them Shut?, Online Learning Practices and Students with Disabilities Social Inclusion 3, 6, p. 84.

${ }^{25}$ D. Xu, S.S. Jaggars (2014), Performance gaps be-tween online and face-to-face courses: Differences across types of students and academic subject are-as, Journal of Higher Education, 85(5), 633-659.

26 WAI. Introduction to understanding WCAG 2.0. Retrieved from http:/ / www. w3.org/TR/UNDERSTAN DING-WCAG20/intro.htm 
1.4. Distinguishable - make it easier for users to see and hear content, including separating foreground from background.

2.1. Keyboard accessible - make all functionality available from a keyboard.

2.2. Enough time - provide users enough time to read and use content.

2.3. [Medical]Seizures - do not design content in a way that is known to cause seizures e.g., avoid flashing images

2.4. Navigable - provide ways to help users navigate, find content, and determine where they are.

3.1. Readable - make text content readable and understandable.

3.2. Predictable - make web pages appear and operate in predictable ways.

3.3. Input assistance - help users avoid and correct mistakes.

4.1. Compatible - maximise compatibility with current and future user agents, including assistive technologies. ${ }^{27}$

These guidelines are updated regularly. Despite all these efforts, we are still dealing with unequal access to online content, especially for people with learning difficulties or cognitive limitations, as well as little preparation of teachers to conduct such classes for people with disabilities. ${ }^{28}$

\section{Specific situation of students with mild intellectual disability and ASD in the context of distance education - difficulties and support}

Difficulties in the accessibility, as well as preparation of teachers to conduct online classes pose a threat to the efficiency and quality

27 S. Burgstahler (2015), Opening Doors or Slamming Them Shut?, Online Learning Practices and Students with Disabilities Social Inclusion 3, 6, p. 72.

28 M.A. Gladhart (2010), Determining faculty needs for delivering accessible electronically delivered instruction in higher education, Journal of Postsecondary Education and Disability, 22(3), pp. 185-196; K.D. Roberts, H.J. Park, S. Brown, B. Cook (2011), Universal design for instruction in postsecondary education: A systematic review of empirically based articles. Journal of Postsecondary Education and Disability, 24(1), pp. 5-15. 
of ongoing distance school classes, especially for people with mild intellectual disability and ASD, in the case of which adaptation needs are very large.

First of all, the difficulty for distance education is the very pandemic situation in which society, and above all children with mild intellectual disability and ASD, is placed. The social, educational and family situation that was caused by the COVID-19 epidemic is extremely incomprehensible to children and adolescents. It is a difficult situation for the whole society and, as W. Poleszak and J. Pyżalski point out, the observed experience includes such states that indicate passing through the crisis with its entire dynamics and going through stages from experiencing tension with growing emotions of fear, anger, irritation, through increasing discomfort in everyday life, search of time organization again, to the loss of emotional control, if in the earlier stages no relief of tension takes place. ${ }^{29}$

Children and adolescents with intellectual disability and autism spectrum disorder are in an extremely difficult situation. The authors indicate that the dynamics of emotional burden depends on such components as: social context, family context and personality traits. Understanding of the social situation by people with intellectual disability or with ASD is limited to a varying extent. A change in daily routine can cause growing anxiety, a problem with accepting the lack of previous elements of everyday life. Students with the discussed disabilities often react with anger, aggression and selfaggression to a change in the predictable pattern. This condition may be exacerbated by omnipresent information about the threat to life and health in a situation of contact with other people. The mass media repeat messages incomprehensible to children and adolescents, which also introduce anxiety among their families. Staying at home with a disabled child for numerous hours a day can also build a tense atmosphere among family members. Hour-long care with-

${ }^{29}$ W. Poleszak, J. Pyżalski J. (2020), Psychologiczna sytuacja dzieci i młodzieży w dobie epidemii, [in:] J. Pyżalski (2020), Edukacja w czasach pandemii wirusa COVID-19, $Z$ dystansem o tym, co robimy obecnie jako nauczyciele, Warsaw: Wydawnictwo EduAkcja Sp. z o.o. 
out the possibility of moving, contacting specialists and teachers weakens the mental and physical condition of parents, which can lead to more frequent conflicts between family members, as well as negatively affect the mental condition of a disabled child. It may happen that this situation leads to the shaken sense of security.

Personality factors of a student with intellectual disability or with ASD (with or without intellectual disability) such as perseverance, knowledge of plans, life goals and ability to implement them in their own lives are very limited in ordinary everyday situations. The pandemic is not even more a condition for increasing the mobilisation to achieve one's goals or perseverance in overcoming the daily difficulties of staying at home most of the time. It is also hard to talk about attempts to look for positive elements of the situation in order to improve comfort.

Experiencing the crisis situation is difficult in the face of a pandemic for most students, and although at first the situation seemed to be temporary, which would last only for a while, finally the students have been "stuck" in online education for numerous weeks with very unclear rules for returning to intramural education.

The family situation of a child with intellectual disability and ASD in the face of online education is extremely complicated. It results from the specific nature of the functioning of such children their ability to increase attention, motivation to make intellectual effort outside of school, cognitive abilities, as well as the severity of autism spectrum disorder symptoms.

Secondly, the problem is the organisation of distance education. Preparation of materials for distance education of students with mild intellectual disability and ASD is particularly difficult because of the specific nature of the learning process resulting from the development opportunities presented above. This obligates to use a significant individualisation. Transmission of contents in a manner consistent with the needs of these students requires diverse digital competencies of teachers. Those that will enable their students to learn based on contact, the concrete reality of a specific structure, form that allows independent work of the student, with the help of 
their parents if necessary, also considering the digital competence of the student and their family, as well as the availability of equipment, the Internet, etc., additionally considering the ability to focus attention, communication, fatigability, the ability to work independently on a task, search for messages, reading comprehension, etc. The selection of contents, the scope of material to teach is also a challenge for teachers. This requires diagnosing the student concerning the extent to which it is possible to teach the general education program online, and the extent to which it is impossible. This also requires determining whether it is more important to maintain the knowledge and skills of the child, which they have already acquired in the course of previous education, or shape new competencies, or maybe only maintain a relationship with the student? The process of the evaluation of the student, the way it should look like and the issues it should concern are also difficult. Attention should be paid to whether the evaluation relates to the child's knowledge, skills or digital competencies, which may constitute an insurmountable threshold for the student. All these elements will determine the effectiveness of distance education of students with mild intellectual disability and with ASD.

The possibilities of supporting distance education in the current epidemiological situation in Poland and in the world pose a huge challenge to the school, teachers, therapists and parents. Therefore, it is necessary to raise a question concerning the most important elements in the whole approach to online teaching. When considering all the strengths and weaknesses of learning educational content, it should be emphasised that the most important thing is to maintain a healthy relationship between the student and the teacher as well as between the student and their parents and siblings. Creating a healthy relationship is aimed at ensuring the child's psychological comfort. It is important here to explain the situation as much as possible, supporting it with visuals - pictures, films. Visual transmission is of great importance here, because many people with intellectual disability and in particular people with ASD visually receive much more information than aurally. It is also important to 
modify the daily schedule. There is a chance that organising and setting a new daily schedule will provide the child with a sense of security and greater predictability of what will happen.

In distance education, the form in which it takes place and the way it is adapted to the needs and abilities of both the child and the whole family are also important:

My child is 10 years old, they have autism and severe intellectual disability. They do not speak, do not understand the instructions directed to them, they are bad at using communication with pictures - they use only two pictures related to food. Favourite activities are walking, jumping and running as well as waving various objects. They attend the second grade in a school and education centre. In the current situation, teachers send tasks to complete at home. It is not possible for my child to sit down in front of the computer and listen to the teacher and feel like contacting them via the Internet. Therefore, we receive tasks to complete at home: worksheets for drawing, colouring, connecting elements, tracing letters, recalculating... My child has autism and severe intellectual disability. It is necessary to remind them to go to the toilet, they need help to get dressed, prepare food, wash themselves and organise every moment of the day. They neither count nor trace letters. They do not understand the instructions directed to them. Therefore, we organise ourselves - we teach them daily activities, try to introduce new symbols for communication. The only question is what my child did during those 1.5 years at school before... A view of mother of a child with ASD

Distance education reveals many aspects of the previous approach to the student: both strengths and weaknesses. It is worth considering here whether the problem is the lack of appropriate materials that can be sent to parents for education at home, or maybe the lack of knowledge about the student's abilities?

It is necessary to provide children and adolescents with information about the spreading disease and the risks associated with it to the possible extent. A lot of specialised materials in the form of films or leaflets, whose task is to draw children's attention to the 
most important aspects of the situation appeared in the mass media. It should be remembered that children with intellectual disability, as well as children with ASD - also those with normal intellectual capacity - understand transmitted information very literally, with a strong emotional context, perceiving many things very individually. It is important, therefore, that the materials which are present to students do not intensify the fear, and focus more on solutions and guidelines to undertake activities for health care.

It is also important to take care of family and peer relationships. This applies on the one hand to the support of parents in building their competencies related to teaching their children at home, maintaining their psychophysical condition while caring for a child with a disability, and on the other hand, to attempts to continue peer relationships, which usually before the pandemic were not particularly developed and maintained by children with intellectual disability and ASD. W. Poleszak and J. Pyżalski indicate that numerous students, before the pandemic situation, maintained not only real, face to face contacts, but also communicated using electronic devices via various communicators, Facebook, and mobile phone. ${ }^{30}$ This possibility is still available to many of them, but in the case of children with intellectual disability and ASD, this contact before the pandemic was usually minimal. First of all, the discussed group of children and adolescents, does not belong to the group of children who gather around them a large group of friends with whom they also willingly keep in touch online, secondly, as indicated by studies of the European Union Agency for Fundamental Rights ${ }^{31}$ (2015) children and adolescents with disabilities more often are victims of peer violence, including cyberbullying.

30 W. Poleszak, J. Pyżalski (2020), Relacje przede wszystkim - nawet jeśli obecnie jedynie zapośredniczone, [in:] J. Pyżalski (2020), Edukacja w czasach pandemii wirusa COVID-19, Z dystansem o tym, co robimy obecnie jako nauczyciele, Warsaw, Wydawnictwo EduAkcja Sp. z o.o.

${ }^{31}$ FRA - European Union Agency for Fundamental Rights(2015), Przemoc wobec dzieci niepełnosprawnych: prawodawstwo, polityki i programy w UE, https:/ / fra.europa.eu/sites/default/files/fra_uploads/fra-2015-violence-againstchildren-with-disabilities-summary_pl.pdf [access on 18.05.2020]. 
Another aspect is the adaptation of materials for distance education. Many children with intellectual disability as well as with ASD need to learn using concrete material, which introduces difficulty in carrying out some of the tasks. Therefore, it is worth considering showing parents what objects in the immediate environment to use and what activities to organise for them. It may also be helpful to record simple instructional videos in which it will be presented how to perform a given task. Worksheets are of course an easier and faster solution, but many materials are inadequate to the child's abilities. Many of the children discussed above primarily need support in the development of communication and self-care skills. Therefore, it is worth focusing on communication aspects in distance learning. Some children using AAC systems may have difficulty understanding the online message. Preparation of content developed on the system used by the student supports their communication capabilities as well as acquiring knowledge. Sometimes it is worth focusing only on the use of the system by the family, because communication is above all the most important thing. When adjusting the materials to the needs of these students, the basic question concerning the content they introduce should be raised. In this difficult period they should be selected with great care. It is necessary to analyse whether students with mild intellectual disability and with ASD have the ability to master them themselves, or whether it is better to fix already known content. Children learning online must be successful, which will build their self-esteem, but also their motivation to make the effort of education. The person primarily responsible for achieving this success is the teacher, as they should prepare the process of distance education of children in such a way as to enable them to obtain a positive evaluation of their work.

\section{Summary}

The situation which was faced by the society around the world when fighting against the COVID-19 pandemic is unique, rare and unexpected. Humanity stood face to face with a change in lifestyle, 
reorganisation of opportunities to take up a job, maintaining social relations, as well as in the face of different family functioning. In addition to the numerous difficulties which are experienced by each family, one of the hardest ones is the organisation of education of children with intellectual disability and autism spectrum disorder. The guidelines presented in the text are only guidelines for attempts to organise distance education of this group of students. It is difficult to talk here about ideal solutions, or about proven solutions. It is difficult, because we all were placed in this situation suddenly and without preparation. Despite this, it is worth remembering that the most important thing in online education of children is not focusing on teaching the general education program, but above all ensuring them a sense of security and maintaining those skills with which disabled students have been sent home for many weeks to give them the chance to return to intramural education ready to acquire further knowledge, skills and competencies.

\section{References}

Amaral J.L, Collins S., Bohache K.T., Kloos H. (2012), Beyond the Black-and-White of Autism: How Cognitive Performance Varies with Context, [in:] Current Topics in Children's Learning and Cognition, Edited by Heidi Kloos, Bradley Morris, Joseph Amaral, chapter 6, pp. 105-122.

Baron-Cohen S. (2001), Theory of mind in normal development and autism: Prisme, 34, pp. 174-183.

Brunsdon V.E.A., Colvert E., Ames C., Garnett T., Gillan N., Hallett V., Lietz S., Woodhouse E., Bolton P., Happe F. (2015), Exploring the cognitive features in children with autism spectrum disorder, their co-twins, and typically developing children within a population-based sample, Journal of Child Psychology and Psychiatry, 56: 8, pp. 893-902.

Buchnat M. (2015), Formy organizacyjne kształcenia dziecka z lekka niepetnosprawnościa intelektualna a jego kompetencje społeczne, Poznań, Wydawnictwo Naukowe UAM.

Burgstahler S. (2015), Opening Doors or Slamming Them Shut? Online Learning Practices and Students with Disabilities Social Inclusion 3, 6, pp. 69-79.

Cangialose A., Allen P.J. (2014), Screening for autism spectrum disorders in infants before 18 months of age, Pediatric nursing 40(1), pp. 33-37. 
Coombs N. (2010), Making online teaching accessible: Inclusive course design for students with disabilities, San Francisco: Jossey-Bass.

Cortesi S., Hasse A., Lombana-Bermudez A., Kim S., Gasser U. (2020), Youth and digital citizenship + (plus): Understanding skills for a digital world. Youth and Media, Berkman Klein Center for Internet \& Society. Retrieved from: https:// cyber.harvard.edu/publication/2020/youth-and-digital-citizenship-plus (access: 20.05.2020).

Dekowska M., Jaśkowski P. (2011), W świecie masek, czyli o tym, jak osoby z autyzmem spostrzegaj ludzka twarz, Roczniki psychologiczne, volume XIV, no. 1, pp. 91-125.

Fichten C.S., Ferraro V., Asuncion J.V., Chwojka C., Barile M., Nguyen M.N., Klomp R., Wolforth J. (2009), Disabilities and e-learning problems and solutions: An exploratory study, Educational Technology and Society, 12(4), pp. 241-256.

FRA - European Union Agency for Fundamental Rights (2015), Przemoc wobec dzieci niepełnosprawnych: prawodawstwo, polityki i programy w UE, https:/ / fra.europa.eu/sites/default/files/fra_uploads/fra-2015-violence-against-children -with-disabilities-summary_pl.pdf [access on 18.05.2020].

Frith U. (2008), Autyzm: Wyjaśnienie tajemnicy, Gdańsk, GWP.

Gajdzica Z. (2011), Sytuacje trudne w opinii nauczycieli klas integracyjnych, Cracow, Oficyna Wydawnicza "Impuls”.

Gladhart M.A. (2010), Determining faculty needs for delivering accessible electronically delivered instruction in higher education, Journal of Postsecondary Education and Disability, 22(3), pp. 185-196.

Głodkowska J. (2000), Pomóżmy dziecku z upośledzeniem umystowym doświadczać przestrzeni, Warsaw, Wyd. WSPS.

Hedvall A.L. (2014), Autism in preschool children: Cognitive aspects and interventions, Printed in Gothenburg, Sweden, Ale Tryckteam, Bohus.

Heiman T. (2008), Females with learning disabilities taking on-line courses: Perceptions of the learning environments, coping and wellbeing, Journal of Postsecondary Education and Disability, 21(1), pp. 4-14.

Jęczeń U. (2003), Uwarunkowania rozwoju kompetencji językowej i komunikacyjnej u dzieci upośledzonych umystowo, Logopedia, 32, pp. 127-138.

Keeler C.G., Horney M. (2007), Online course designs: Are special needs being met?, American Journal of Distance Education, 21(2), pp. 61-75.

Keen D. (2009), Engagement of Children with Autism in Learning, Australasian Journal of Special Education, Volume 33, Issue 2, pp. 130-140.

Kościelak R. (1989), Psychologiczne podstawy upośledzonych umystowo, Warsaw, Wyd. Naukowe PWN.

La Malfa G., Lassi S., Bertelli M., Salvini R., Placidi G.F. (2004), Autism and intellectual disability: a study of prevalence on a sample of the Italian population, Journal of Intellectual Disability Research, 48(3), pp. 262-267.

Mitchell D. (2008), What Really Works in Special and Inclusive Education, London New York: Routledge. 
National Council on Disability (2004), Design for inclusion: Creating a new marketplace. National Council on Disability Website. Retrieved from http://www. ncd.gov/newsroom/publications/2004/online_newmarketplace.htm

Nęcka E. (2003), Inteligencja: geneza - struktura - funkcje, Gdańsk, GWP, Oficyna Wydawnicza "Impuls”.

Pisula E. (2015), Autyzm. Od badań mózgu do praktyki psychologicznej, Gdańsk, GWP.

Plichta P. (2018), The use of information and communication technologies by young people with intellectual disabilities in the context of digital inequalities and digital exclusion, "E-Methodology", 5(5), pp. 11-23.

Pluta A. (2012), Mechanizmy poznawcze teorii umystu, Roczniki psychologiczne, volume XV, no. 1, pp. 7-30.

Poleszak W., Pyżalski J. (2020), Psychologiczna sytuacja dzieci i młodzieży w dobie epidemii, [in:] J. Pyżalski, Edukacja w czasach pandemii wirusa COVID-19, Z dystansem o tym, co robimy obecnie jako nauczyciele, Warsaw, Wydawnictwo EduAkcja Sp. z o.o.

Poleszak W., Pyżalski J. (2020), Relacje przede wszystkim - nawet jeśli obecnie jedynie zapośredniczone, [in:] J. Pyżalski, Edukacja w czasach pandemii wirusa COVID-19, $Z$ dystansem o tym, co robimy obecnie jako nauczyciele, Warsaw, Wydawnictwo EduAkcja Sp. z o.o.

Prentka M. (2015), Aetiology of Theory of Mind disorders for people with Autism Spectrum Disorder. Neurocognitive therapeutic intervention, Transdyscyplinarne Studia o Kulturze (i) Edukacji, 10, pp. 87-100.

Pyżalski J. (2019a), Cyfrowa pedagogika medialna, [in:] Z. Kwieciński, B. Śliwerski (ed.), Pedagogika. Podręcznik akademicki, Warsaw, Wydawnictwo Naukowe PWN SA.

Roberts J.B., Crittenden L.A., Crittenden J.C. (2011), Students with disabilities and online learning: A cross-institutional study of perceived satisfaction with accessibility compliances and services, Internet and Higher Education, 14(4), pp. 242-250.

Roberts K.D., Park H.J., Brown S., Cook B. (2011), Universal design for instruction in postsecondary education: A systematic review of empirically based articles, Journal of Postsecondary Education and Disability, 24(1), pp. 5-15.

Smahel D., Machackova H., Mascheroni G., Dedkova L., Staksrud E., Ólafsson K., Livingstone S., Hasebrink U. (2020), EU Kids Online 2020: Survey results from 19 countries, EU Kids Online.

Sowden H., Perkins M., Clegg J. (2008), The co-development of speech and gesture in children with autism, Clinical Linguistics and Phonetics, 22(10-11), pp. 804-813.

Stefańska-Klar R. (2005), Późne dzieciństwo. Młodszy wiek szkolny, [in:] B. Harwas-Napierała, J. Trempała (red.), Psychologia rozwoju człowieka (vol. 2, pp. 130-163). Warszawa, Wyd. Naukowe PWN.

Thomson R., Fichten C.S., Havel A., Budd J., Asuncion J. (2015), Blending universal design, e-learning, and information and communication technologies, [in:] S. Burgstahler (ed.), Universal design in higher education: From principles to practice (pp. 275-284). Cambridge, MA: Harvard Education Press. 
WAI. Introduction to understanding WCAG 2.0. Retrieved from http://www. w3.org/TR/UNDERSTAN DING-WCAG20/intro.htm

Wyczesany J., Gajdzica Z. (2006), Uwarunkowania edukacji i rehabilitacji uczniów o specjalnych potrzebach rozwoju, Kraków, Wyd. Naukowe AP.

Xu D., Jaggars S.S. (2014), Performance gaps between online and face-to-face courses: Differences across types of students and academic subject are-as, Journal of Higher Education, 85(5), pp. 633-659. 